\title{
THE METHOD OF AUTOMATED DEVELOPMENT OF AN ASSEMBLY DRAWING OF A CABLE NETWORK
}

\author{
A. M. Butin*, E. U. Dubrovskiy, E. V. Dobyshev, S. V. Efremov, S. B. Suntsov \\ JSC “Academician M. F. Reshetnev "Information Satellite Systems" \\ 52, Lenin Str., Zheleznogorsk, Krasnoyarsk region, 662972, Russian Federation \\ * E-mail: butinandr@gmail.com
}

The final stage of designing a cable network of spacecraft (as well as any other product) is the release of design and operational documentation. The automation of this process allows to improve the quality of documentation and decrease the manufacturing time of spacecraft.

The JSC "Information Satellite Systems" (ISS) uses its own integrated software complex "ALCAB" for releasing design documentation package for a cable network. For the assembly drawing development, the company uses CAD without integration with "ALCAB". In this regard, adding or removing items in the specification leads to the further refinement of the drawing.

We propose the technique of solving a problem connected to the automation of the assembly drawing development for a cable network produced on a plane. The main task is to create associative link between the specification items and the cable network drawing. In this article we present the results of the analysis of the structure of the cable network $3 D$ model designed in "CATIA V5" CAD. There are schematic examples of harness topologies. The analysis identified the list of data to be extracted from the $3 D$ model.

We described the most interesting tools of "CATIA V5" CAD that allow you to automate many processes including the development of your own software solutions. The analysis identified the tools for automated uploading of all required data from the model. The examples of these tools are "Knowledge Expert" and external programming environment "CAA RADE". The analysis of their performance showed that the extraction of data using an algorithm developed with "CAA RADE" was faster than using "Knowledge Expert".

We described the potential of drawing tools in "CATIA V5" CAD such as "Electrical Harness Flattening" and "Drafting" that allow you to automate the assembly drawing development.

The paper proposes the method of automating he assembly drawing development of a cable network developed with the use of three-dimensional technology using the tools of "CATIA V5" CAD and software designed at the JSC "ISS".

Keywords: spacecraft, cable network, automation, design documentation, assembly drawing.

Сибирский журнал науки и технологий. 2018. Т. 19, № 2. С. 251-258

\section{МЕТОДИКА АВТОМАТИЗИРОВАННОГО ФОРМИРОВАНИЯ СБОРОЧНОГО ЧЕРТЕЖА КАБЕЛЬНОЙ СЕТИ}

\author{
А. М. Бутин*, Е. Ю. Дубровский, Е. В. Добышев, С. В. Ефремов, С. Б. Сунцов \\ АО «Информационные спутниковые системы» имени академика М. Ф. Решетнева» \\ Российская Федерация, 662972, г. Железногорск Красноярского края, ул. Ленина, 52 \\ * E-mail: butinandr@gmail.com
}

\footnotetext{
Завершающим этапом процесса проектирования кабельной сети космического аппарата, как и любого другого изделия, является выпуск конструкторской и эксплуатационной документации. Автоматизация процесса выпуска комплекта документации на кабельную сеть позволяет повысить качество документации и сократить сроки изготовления космического аппарата.

Выпуск комплекта конструкторской документации на кабельную сеть в АО «ИСС» производится в интегрированном программном комплексе $A L C A B$ собственной разработки. Разработка сборочного чертежа осуществляется вручную с применением двумерных чертежно-ориентированных САПР, не имеющих интеграцуии с ALCAB. В связи с этим внесение или удаление позиций в специификации ведет к доработке чертежа.

Предложена методика решения проблемы, связанной с автоматизачией процесса формирования сборочного чертежа на кабельную сеть, изготовление которой производится на плоскости. Главной задачей, которую необходимо решить при таком подходе к выпуску чертежно-графической документации, является организациия ассоциативной связи между позициями спецификаџии и сборочного чертежа. Приведен результат анализа структуры 3D-модели кабельной сети, спроектированной в САПР CATIA V5. Представлены схематичные примеры топологий жгутов. Анализ позволил выявить перечень данных, которые требуется извлечь из трехмерной модели.
} 
Приведено описание наиболее интересных инструментов, предоставляемых пользователю САПР САТІА V5 и дающих возможность автоматизировать многие задачи, включая разработку собственных программных решений. Анализ позволил выделить инструменты, которые автоматизируют процесс выгрузки всех требуемых данных из модели. К таким инструментам относятся Knowledge Exреrt и внешняя среда программирования CAA RADE. Анализ их быстродействия показал, что выгрузка данных с помощью алгоритма, разработанного в СAA RADE, происходит быстрее, чем с помощью Knowledge Expert.

Перечислены возможности чертежно-графических инструментов САПР CATIA V5, таких как Electrical Harness Flattening u Drafting. Они предоставляют возможность автоматизировать процесс формирования сборочного чертежа.

Предложена методика автоматического формирования сборочного чертежа кабельной сети, разрабатьваемой по трехмерной технологии, с применением инструментов, предоставляемых САПР CATIA V5, и программных решений собственной разработки.

Ключевые слова: космический аппарат, кабельная сеть, автоматизация, конструкторская документация, сборочный чертеж.

Doi: 10.31772/2587-6066-2018-19-2-251-258

Introduction. Introduction of software and hardware automation tools reduces manual work; it allows to significantly increase the quality of science-intensive products, reduce time and financial costs as well as provide the company competitiveness in the high tech segment.

While developing a cable network, engineers of the JSC "ISS" use two designing methods:

1. The first method uses a 3D modeling technology with the use of "CATIA V5" CAD. A designer develops a cable network with a $3 \mathrm{D}$ model of spacecraft (SC): he lays the cables, counts lengths and diameters of segments. A designer uses inputs in the form of connection spreadsheets describing connectors and connections between them (names of connectors, electrical circuits, etc.). Then by using the integrated software complex "ALCAB" he releases a package of design documentation for cables based on a $3 \mathrm{D}$ model of a cable network. The detailed description of the integrated software complex "ALCAB" is presented in the publications [1-4].

Cable networks are made in full size model of SC according to a 3D-model of a cable network (3D-CN) [5]. The technology reduces consumption of wires and materials, provides necessary bending radii, it optimizes the length of electrical circuits, and thus it reduces the cables weight. The model with produced cable network allows transporting it to the assembly workshop without any deformation. This method is suitable for developing a cable network based on a single electrical circuit [6].

2. The second method is standard. The design is carried out using two-dimensional drawing-oriented CADs (nanoCAD, AutoCAD, MS Visio), and production is carried out using an assembly drawing of a cable network on a plane[6].

At present assembly drawings are made manually using two-dimensional CADs without integration with the integrated software complex "ALCAB". In this regard, adding or removing of items in the specification leads to the further refinement of the assembly drawing. This causes the need for a tool for automatic assembly drawing development which is pegged to specification items.

To achieve the goal we need to perform the following tasks [6]:

1. Analyze the 3D-CN structure.

2. Analyze abilities of automation tools for data extraction of 3D-CN and two-dimensional graphic design in
"CATIA" CAD to organize the automatic development of the assembly drawing of $\mathrm{CN}$.

3. Develop a method of development of drawing and associative connections with the items of specification. The drawing being developed must meet the requirements specified in [7].

The structure of 3D model of a cable network in "CATIA" CAD. SC CN has dozens of cable assemblies. Depending on the requirements, each cable assembly may contain several harnesses combining sets of wires and cables separated in SC. Apart from electromagnetic compatibility, the reason of detachment may be materials with low flexibility (elasticity) which a cable is made of; this makes it difficult to set this cable on the product in one harness with other wires and cables.

We developed a topology of $\mathrm{CN}$ by using a 3D model of SC in "CATIA" CAD in the modules "Electrical Part Design" and "Electrical Assembly Design" of the working environment "Equipment and Systems Engineering". In "CATIA" CAD 3D-CN structure is treelike. The harness (Multi-branchable object) consists of branches (Branchable object). Branches, in their turn, consist of segments (Bundle Segment object).

Wires (Wire object) after wiring in module "Electrical Wire Routing" are in the "Electrical Bundle" object. They have a hidden connection to the bundle segments, through which they were laid. Fig. 1 shows 3D-CN containing three bundles (highlighted in different colors).

When a designer lays a cable in a 3D-model of SC, he may develop several topologies for the same cable assembly to determine the most optimal version of the harness laying on a product. Changes in the devices arrangement of SC can be the reason for developing a new topology as well.

For example, the fig. 2 and 3 show possible situations when topology of the harnesses changes. In the first case (fig. 2) S2 segment moves to the branching position of segment S1, consequently, S2 becomes longer (as a result of the movement); $\mathrm{S} 3$ becomes longer as well (combined with S5 segment). The total length of wires of the segments may not change. In the second case (fig. 3) we described unlikely situation when two harnesses $\mathrm{H} 1$ and $\mathrm{H} 2$ were combined into one $\mathrm{H} 3$. 


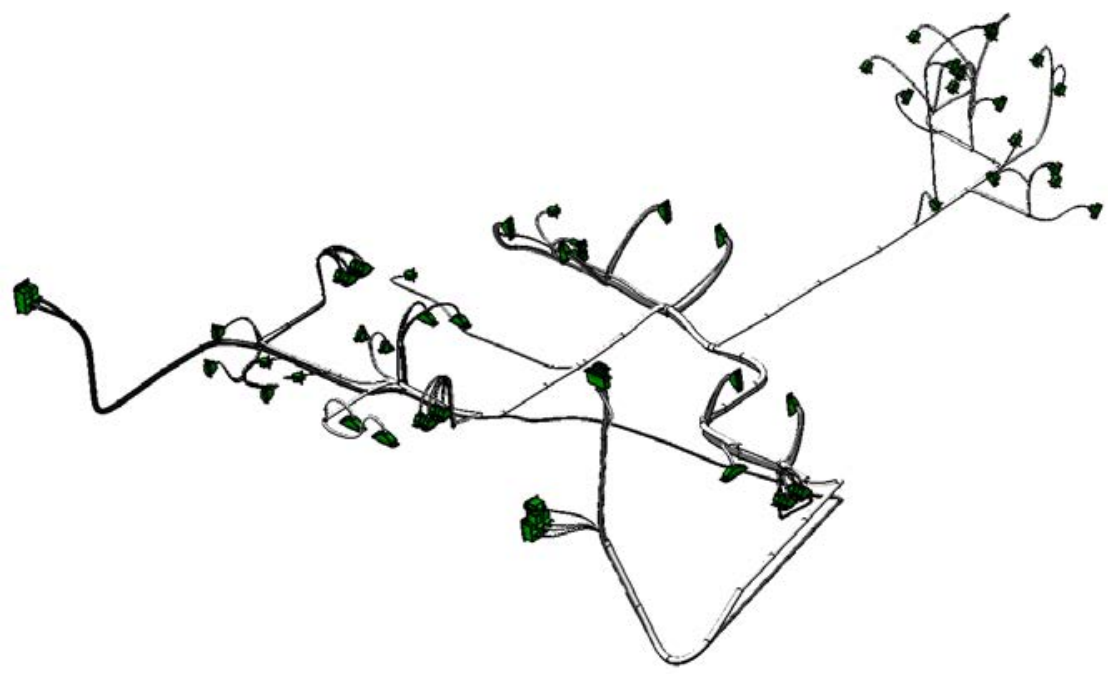

Fig. 1. 3D-model of SC CN

Рис. 1. 3D-модель КС КА

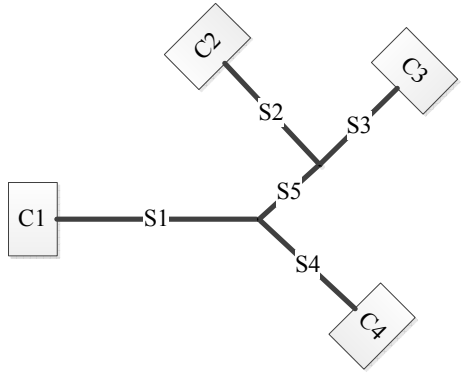

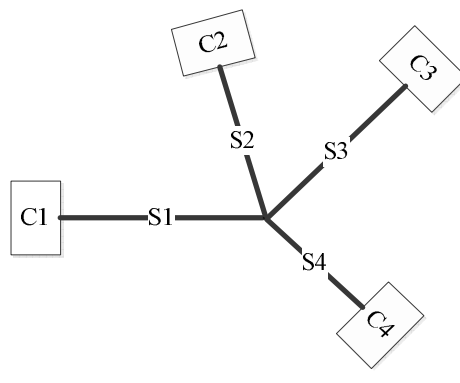

$b$

Fig. 2. Schematic representation of $\mathrm{CN}$ bundle: $a$ - topology of $\mathrm{CN}$ harness before conversion; $b$ - topology of $\mathrm{CN}$ harness after conversion, where $\mathrm{C} 1-\mathrm{C} n$ - connectors, $\mathrm{S} 1-\mathrm{S} n-$ segments of bundle

Рис. 2. Схематичное представление жгута КС: $a$ - топология жгута КС до преобразования; $\sigma$ - топология жгута КС после преобразований, где $\mathrm{C} 1-\mathrm{C} n$ - разъемы, $\mathrm{S} 1-\mathrm{S} n$ - сегменты жгута

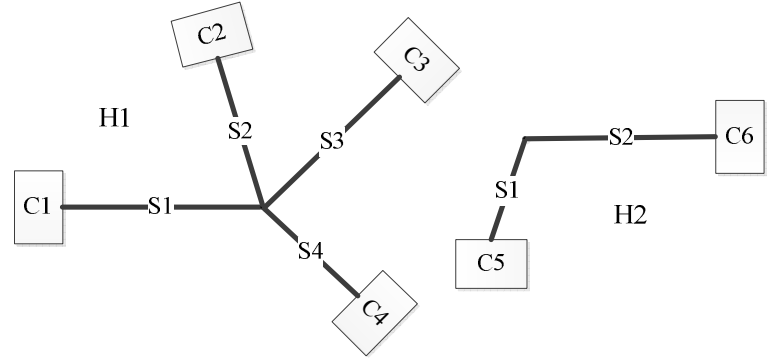

$a$

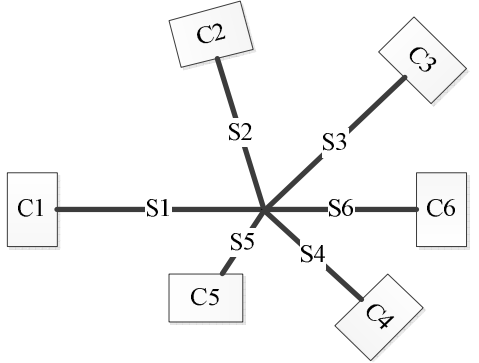

$b$

Fig. 3. Schematic representation of $\mathrm{CN}$ harness: $a$ - topology of $\mathrm{CN}$ harness before combining; $b$ - topology of $\mathrm{CN}$ harness after combining $\mathrm{H} 1$ and $\mathrm{H} 2$ bundles, where $\mathrm{H} 1-\mathrm{H} n$ - harnesses, $\mathrm{C} 1-\mathrm{C} n$ - connectors, $\mathrm{S} 1-\mathrm{S} n-$ segments of harnesses

Рис. 3. Схематичное представление жгутов КС: $a$ - топология жгутов КС до объединения; $\sigma$ - топология жгута КС после объединения жгутов Н1 и Н2, где Н1-Н $n$ - жгуты, $\mathrm{C} 1-\mathrm{C} n$ - разъемы, $\mathrm{S} 1-\mathrm{S} n-$ сегменты жгута 
To organize the association between assembly drawing and specification of $\mathrm{CN}$ we are developing, we need to unload the data from the received model of $\mathrm{CN}$, namely:

- diameters and length of segments and wires;

- lists of wires that pass through each individual segment;

- list of segments included in the bundle;

- coordinates of points of segment connection with neighboring elements (segments, connectors).

Analysis of automation tools of "CATIA" CAD. "CATIA" CAD has rich functionality, it provides a user with not only standard tools, but the opportunity to expand the functionality by developing their own software solutions as well.

All tools can be grouped according to ease of implementation and application efficiency. The following list contains the most interesting tools, grouped in increasing order of complexity of implementation and effectiveness of their application [8-11]:

1. Native tools:

- parameters - characteristic that determines the property of an object or a document;

- table of design parameters - the tool that allows you to manage document parameters by associating the developed document with a text file or "MS Excel" table containing parameter values;

- formulas - the function used to calculate or limit document properties;

- templates - the document that stores some context and is used to generate new documents by changing parameters or replacing the geometry specification;

- reports - the tool that allows you to export data about a document (for example, the lengths and diameters of segments from the $\mathrm{CN}$ model) in accordance with the specified layout of the final document.

2. Knowledge-based applications (Knowledgeware):

- Knowledge Advisor, KWA - the tool that allows you to embed knowledge into a project to automate repetitive design tasks and assist with technical decisions. "KWA" is a list of instructions necessary for the analysis of specific design conditions;

- Knowledge Expert, KWE - similarly, "KWA" allows you to embed knowledge into a project. The tool defines the way of setting and verifying the design rules that must be implemented throughout the project structure in order to comply with technical specifications and standards;

- Product Knowledge Template - allows you to create templates of individual objects, including geometry and elements of knowledge (rules, checks, etc.), for the purpose of further standard design.

3. "Automation API" is a set of objects (OLE, COM, ActiveX) providing a high-level interface with the "CATIA" CAD through built-in "VBScript" and "Visual Basic" languages or any language that supports "OLE" or ".NET" technologies [12].

4. External programming environment "CAA (Component Application Architecture) RADE" (Rapid Application Development Environment). This programming environment provides a low-level access to the component architecture of all Dassault Systemes products. It allows you to develop programs of any complexity from extensions (AddIn) directly built in "CATIA", "ENOVIA" or "DELMIA" to standalone console or interactive programs including "CATIA"-like environment [12].

Reports, "KWE", "Automation API" and "CAA RADE" are the most suitable for extracting geometric parameters (length, diameters) and configuration of $\mathrm{CN}$ model.

The use of reports and the "Automation API" in practice showed that their combined and separate use does not allow us to extract meaningful data about the configuration of a $\mathrm{CN}$ model [12].

But "KWE" and "CAA RADE" allow to solve this problem. Comparison of these tools on small models showed that the algorithm developed on "CAA RADE" unlike "KWE" allows reducing the data export time approximately by $48 \%$ (fig. 4 ). This is due to the fact that "KWE", in contrast to "CAA RADE", does not have flexible sampling of data.

Unlike small models, in larger models the increase in the sampling rate of data is more significant (fig. 5). For example, for the model shown in fig. 1, consisting of more than 900 elements, sample selection using "KWE" took approximately about an hour, while the algorithm developed in "CAA RADE" took approximately 26 minutes.

Based on the results of the analysis, we concluded that the application of the external programming environment "CAA RADE" will achieve the required result in the frame of the task being solved.

Drawing-graphic tools of "CATIA" CAD. Along with 3D design tools, "CATIA" CAD provides the ability to develop drawing and graphic documentation. The "Electrical Harness Flattening" module allows to set out the 3D model of the bundle (fig. 6, $a$ ) into the plane (fig. 6,b) and to be shared with such products as "Electrical Library", "Electrical Harness Installation" and "Electrical Wire Routing". This module provides the following basic functions $[8 ; 13 ; 14]$ :

- flattening of bundle segments;

- rotation or bending of the segments of the bundle at a certain point;

- scaling of the segments of the bundle (setting the dummy length);

- synchronization of the drawing with the model;

- selecting the type of drawing view;

- automatic annotation of the drawing.

Using the functions provided by the "Drafting" module, the user can make a drawing by generating a projection of the bundle put on the plane (fig. 7) and then indicate the dimensions and other textual information [15].

Due to the fact that the existing technology of 3D design does not imply full description of the 3D model of $\mathrm{CN}$, and it does not contain information about some of the materials in the composition of $\mathrm{CN}$ (for example, tags, threads, braids, tubes, printed circuit boards, nuts, etc.), information about them will not be depicted on the drawing. This problem can also be solved using the "Automation API" or "CAA RADE" tools. 


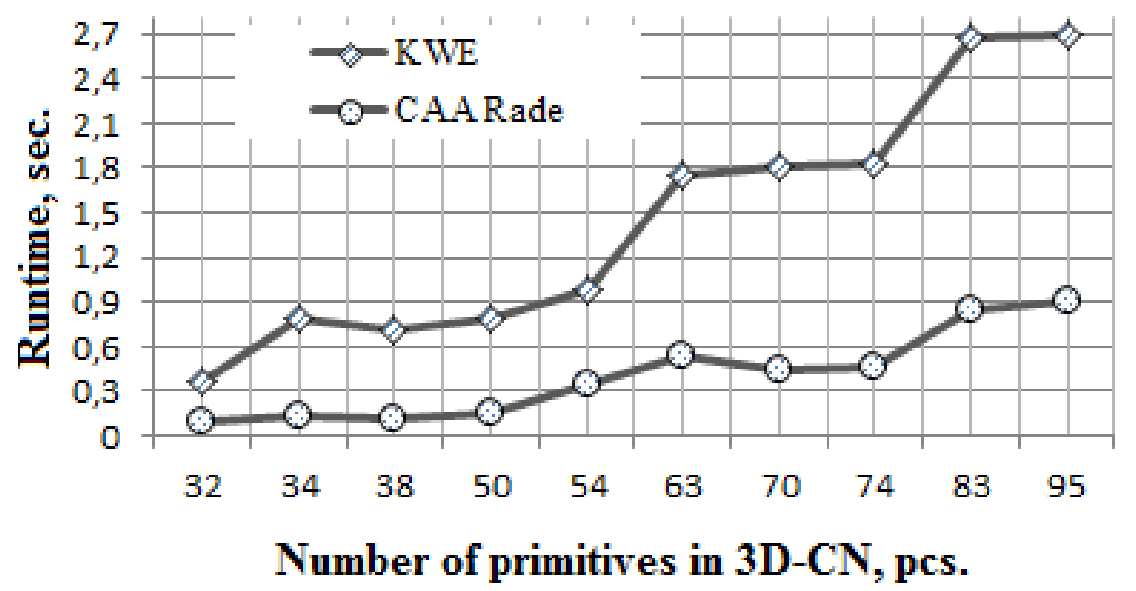

Fig. 4. The graph comparing the speed of algorithms on small models [6]

Рис. 4. График сопоставления быстродействия алгоритмов на небольших моделях [6]

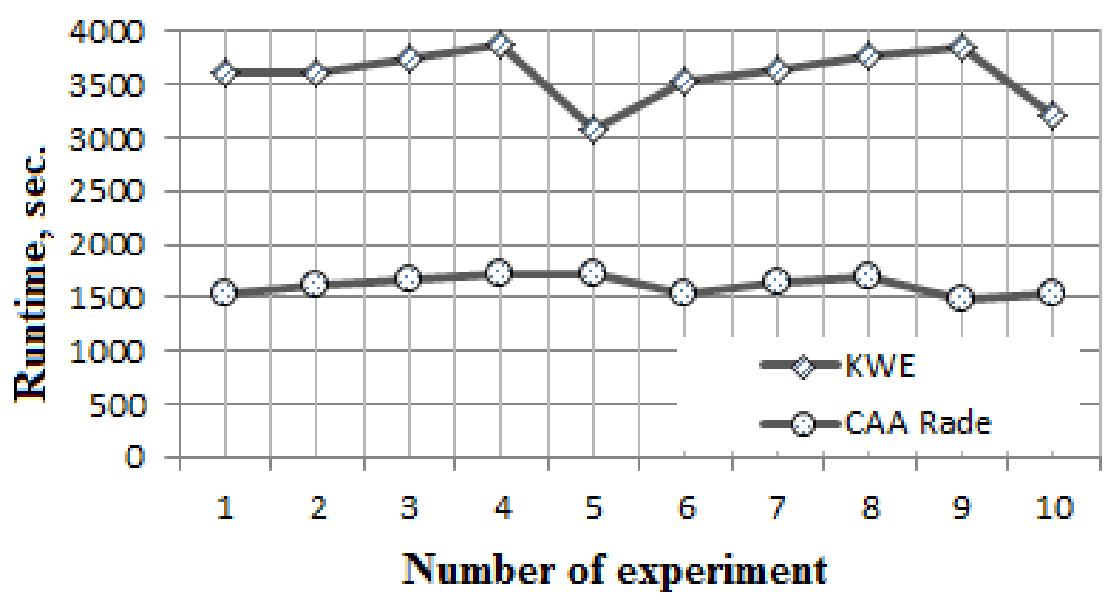

Fig. 5. The graph comparing the speed of algorithms on large models

Рис. 5. График сопоставления быстродействия алгоритмов на большой модели
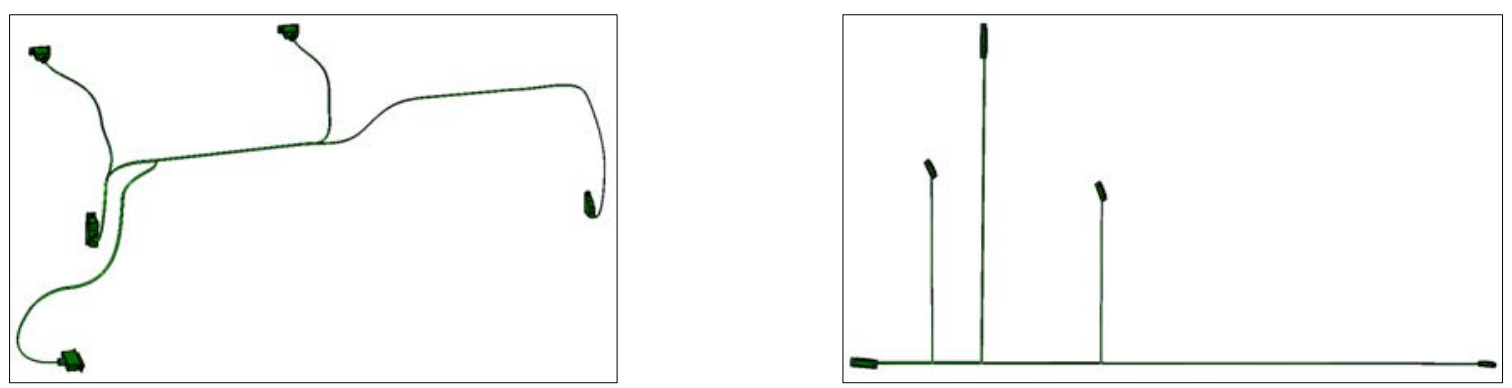

$a$

Fig. 6. 3D-model of SC CN: $a-$ in 3D; $b-$ on a plane surface

Рис. 6. 3D-модель КС КА: $a$ - в трехмерном контексте; $\sigma$ - на плоскости 


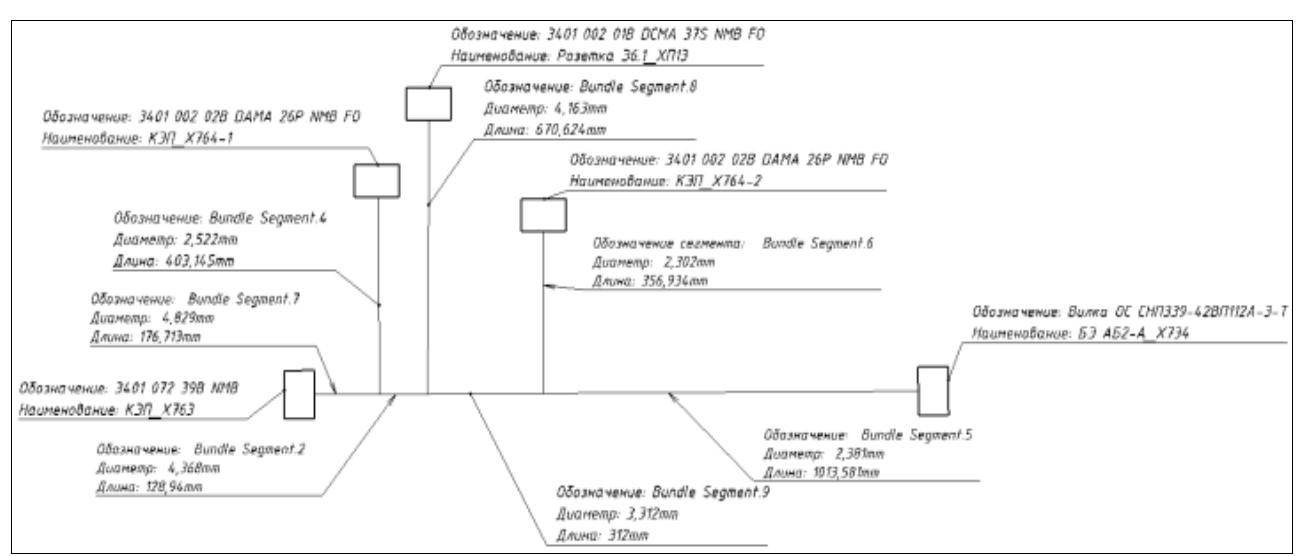

Fig. 7. Drawing of a cable network according to orientation

Рис. 7. Чертеж КС по раскладке

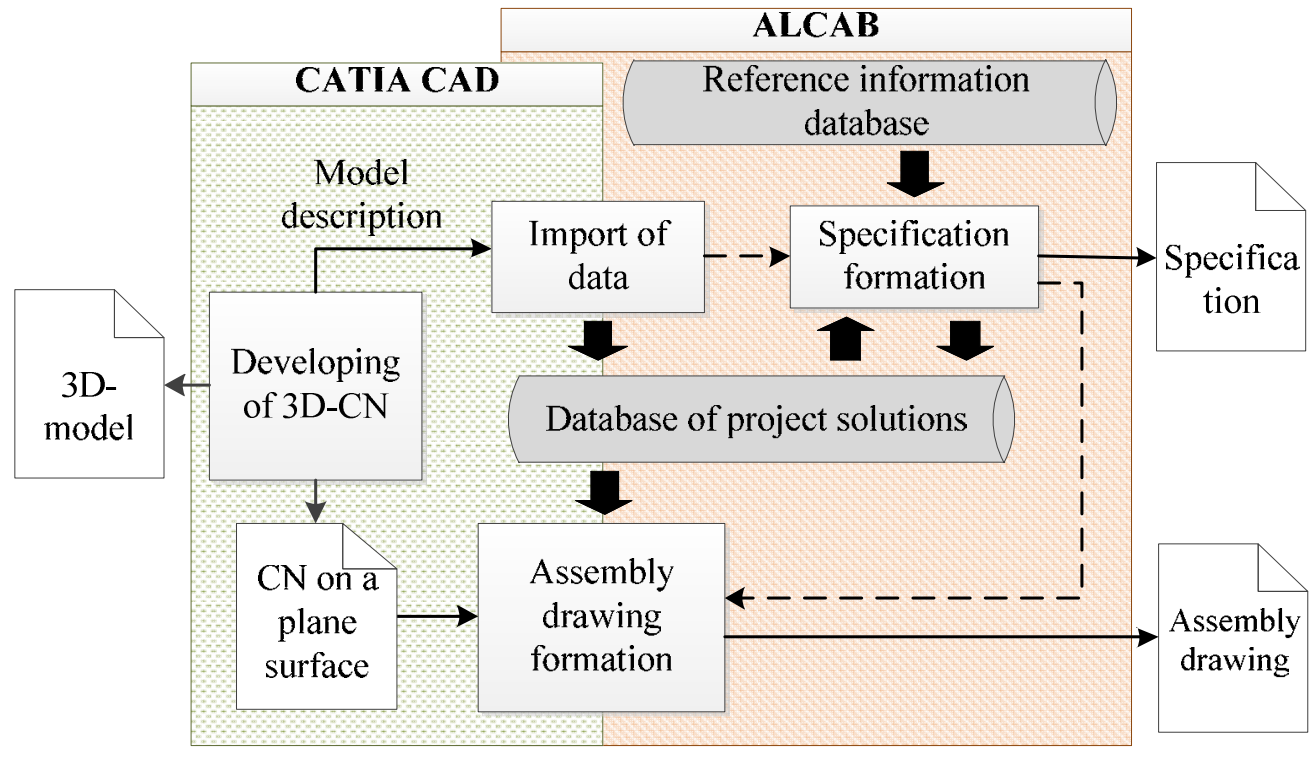

Fig. 8. The interaction pattern of the integrated software complex "ALCAB" and "CATIA" CAD

Рис. 8. Схема взаимодействия САПР САТІА

и интегрированного программного комплекса ALCAB

The method of forming an assembly drawing. Taking into account the results of the analysis, we can organize the development of assembly drawing of $\mathrm{CN}$ in the following way (fig. 8).

After completing the development of $\mathrm{CN}$ topology, a designer exports the data containing configuration and geometric parameters from the "CATIA" CAD to the integrated software complex "ALCAB". The specification is generated automatically according to the received data from "CATIA" CAD. In the module "Electrical Harness Flattening" a designer puts the volumetric bundle in the plane. Then, in the "Drafting" module, he generates the projection of the bundle and activates the process of automated arrangement of positions obtained from the specification.

Conclusion. Currently, we are working on the integration of the functional of the "Electrical Harness Flatten- ing" module into the design process of the $\mathrm{CN}$ and automating the associative linking of the specification items to the drawing and a graphic document and bringing the final result to the requirements of Unified system for design documentation.

We developed a tool for unloading geometric parameters and configurations from the $\mathrm{CN}$ model, the control principle and the structure of the centralized storage of the received data. Thus, we optimized the selection of materials for the segments and expanded the capabilities of the integrated software complex "ALCAB" in the development of new tools that automate such complex tasks as the selection of shipping containers for terrestrial $\mathrm{CN}$ according to mass-dimensional characteristics.

Thus, the developed method will allow to:

- automate the process of issuing drawings and graphic documents for $\mathrm{CN}$; 
- provide the process of automated release of design documentation in the integrated software complex "ALCAB" with all necessary data;

- reduce the labor costs for manual development of design documentation;

- reduce the impact of the human factor and, as a consequence, improve the quality of the design documentation;

- automate the annotation of the 3D model of $\mathrm{CN}$.

\section{References}

1. Dobyshev E. V., Yushkova A. V., Pinaev F. A., Butin A. M., Yutkin A. V., Klimkin O. A., Strel'chuk E. S., Dubrovskii E. Y., Boldyreva O. O. Avtomatizirovannaya razrabotka konstruktorskoi dokumentatsii na izgotovlenie $i$ ispytanie kabel'nykh setei kosmicheskikh apparatov $A L-$ $C A B$ V2 [Computer-aided development of design documentation for production and testing a harnesses of spacecraft]. Patent RF, No. 2017612882, 2017.

2. Butin A. M., Dubrovsky E. Y., Klimkin O. A., Dobyshev E. V., Suntsov S. B. [Organization of computer aided design and electrical control onboard cable network of the spacecraft in the JSC "ISS"]. Naukoenkie tekhnologii. 2015, Vol. 16, No. 3, P. 14-16 (In Russ.).

3. Dzyuvina A. V., Dobyshev E. V., Klimkin O. A. [Creation of a model of a unified information space in the framework of the development of a technique for designing a cable network of a spacecraft in JSC "ISS"]. $S b$. trudov $V$ Obshcherossiiskoi molodezhnoi nauchnotekhnicheskoi konferentsii "Molodezh'. Tekhnika. Kosmos" [Proc. of the 5th All-Russian Young Scientific and Technical Conference "Young. Equipment. Space"]. St. Petersburg, BSTU Publ., 2013, P. 260-262 (In Russ.).

4. Dzyuvina A. V., Dobyshev E. V., Efremov S. V., Klimkin O. A. [Development of a methodology for designing a cable network of a spacecraft in JSC "ISS" using CALS-technologies] Vestnik BGTU. 2013, No. 17, P. 41-42 (In Russ.).

5. Kochura S. G. Sholniy V. N. Suntsov S. B. Efremov S. V. [The development of onboard harness new technologies]. Vestnik NPO im. S. A. Lavochkina. 2015, No. 03, P. 118-120 (In Russ.).

6. Butin A. M., Dubrovsky E. Y., Dobyshev E. V., Efremov S. V. [Development of the cable network assembly drawing automatic generation technology]. Sb. trudov IV Nauchno-tekhnicheskoi konferentsii molodykh spetsialistov AO "ISS": "Razrabotka, proizvodstvo, ispytaniya $i$ ekspluatatsiya kosmicheskikh apparatov $i$ system" [Proc. of the 4th Scientific and Technical Conference of Young Specialists of JSC "ISS" Development, production, testing and exploitation of spacecraft and systems]. Zheleznogorsk, JSC “ISS”, 2017, P. 200-201 (In Russ.).

7. GOST 2.414-75. Edinaya sistema konstruktorskoi dokumentatsii. Pravila vypolneniya chertezhei zhgutov, kabelei i provodov. [Unified system of design documentation. Rules for drawing drawings of harnesses, cables and wires]. Moscow, Standartinform Publ., 2011, 34 p. (In Russ.).

8. “Catia Version 5 Release 24”. User's Documentation. Dassault Systèmes, 2014.
9. Laundanski M., Ruschitzka M., Wrobel J. Parametric models of mould tools in CATIA V5. Proc. of the Fourth International Seminar and Workshop, EDIProD Zielona Gora, Poland. 2004, P. 223-228.

10. Lohith M. L., Laxmi Prasanna, Devaraja Holla Vaderahobli. Translating MOKA based Knowledge models into a Generative CAD model in CATIA V5 using Knowledgeware. Proc. of the 2013 World Congress in Computer Science, Computer Engineering and Applied Computng, Las Vegas, USA. 2013. Available at: http://worldcomp-proceedings.com/proc/p2013/MSV3174.pdf (accessed: 06.11.2017).

11. Forum russkoyazychnykh pol'zovatelei CATIA. PLM-forum.ru [Forum of Russian Users CATIA. PLMforum.ru]. Available at: www.plm-forum.ru/forum (Access: 17.01.17).

12. "CAA V5 Encyclopedia". User's Documentation. Dassault Systèmes, 2013.

13. Ljah S. [Designing of industrial facilities, equipment and systems with the help of CATIA V5]. Informacionno-analiticheskij zhurnal "Rational Enterprise Management". 2009, No. 6 (In Russ.). Available at: http://www.remmag.ru/admin/upload_data/remmag/096/DS.pdf (accessed: 06.10.2017).

14. "Electrical Harness Flattening". User's Guide CATIA V5 Release 14. Available at: http://www.catiadesign.org/_doc/v5r14/catpdfehfug_C2/e hfug.pdf (accessed: 06.10.17).

15. Novikov I., Bubnov A. [Designing electrical systems from Dassault Systemes and IGE + XAO Group]. SAPR $i$ grafika. 2006, No. 1 (In Russ.). Available at: http://www.sapr.ru/article.aspx?id=14860\&iid=705 (accessed: 26.01.2017).

\section{Библиографические ссылки}

1. Автоматизированная разработка конструкторской документации на изготовление и испытание кабельных сетей космических аппаратов ALCAB V2 : свид. о гос. регистрации программы для ЭВМ / Добышев Е. В., Юшкова А. В., Бутин А. М. и др. Российская Федерация. № 2017612882. Зарегистрировано в Реестре программ для ЭВМ 06.03.2017.

2. Организация автоматизированного проектирования и электрического контроля бортовой кабельной сети космического аппарата в АО «ИСС» / А. М. Бутин [и др.] // Наукоемкие технологии. 2015. Т. 16. № 3/ C. 14-16.

3. Дзювина А. В., Добышев Е. В., Климкин О. А. Создание модели единого информационного пространства в рамках разработки методики проектирования кабельной сети космического аппарата в ОАО «ИСС» // Молодежь. Техника. Космос : сб. тр. V Общерос. молодежной науч.-техн. конф. СПб. : БГТУ, 2013. С. 260-262.

4. Разработка методики проектирования кабельной сети космического аппарата в ОАО «ИСС» с использованием ИПИ-технологий / А. В. Дзювина [и др.] // Вестник БГТУ. 2013. № 17. С. 41-42.

5. Развитие новых технологий бортовой кабельной сети / С. В. Ефремов [и др.] // Вестник НПО им. С. А. Лавочкина. 2015. № 3. С. 118-120. 
6. Разработка технологии автоматического формирования сборочного чертежа кабельной сети / А. М. Бутин [и др.] // Разработка, производство, испытания и эксплуатация космических аппаратов и систем : сб. IV науч.-техн. конф. молодых специалистов АО «ИСС». Железногорск, 2017. С. 200-201.

7. ГОСТ 2.414-75. Единая система конструкторской документации. Правила выполнения чертежей жгутов, кабелей и проводов. М. : Стандартинформ, $2011.34 \mathrm{c}$.

8. Интерактивная документация «САTIA V5 Release 24» из стандартного комплекта поставки // Dassault Systèmes. 2014.

9. Laundanski M., Ruschitzka M., Wrobel J. Parametric models of mould tools in CATIA V5 // Proc. of the Fourth International Seminar and Workshop, EDIProD. 2004. P. 223-228.

10. Lohith M. L., Laxmi Prasanna, Devaraja Holla Vaderahobli. Translating MOKA based Knowledge models into a Generative CAD model in CATIA V5 using Knowledgeware [Электронный pecypc] // Proc. of the 2013 World Congress in Computer Science, Computer Engineering and Applied Computng. URL: http://worldcomp-proceedings.com/proc/p2013/ MSV3174.pdf (дата обращения: 06.11.2017).
11. Форум русскоязычных пользователей CATIA [Электронный peсурс] // PLM-forum.ru. URL: www.plm-forum.ru/forum (дата обращения: 17.01.17).

12. Интерактивная документация «CAA V5 Encyclopedia» из комплекта поставки // Dassault Systèmes. 2013.

13. Лях С. Проектирование промышленных объектов, оборудования и систем с помощью CATIA V5 [Электронный ресурс] // Рациональное управление предприятием. 2009. № 6. URL: http://www.remmag.ru/admin/upload data/remmag/ 09-6/DS.pdf (дата обращения: 06.10.17).

14. "Electrical Harness Flattening" User's Guide CATIA V5 Release 14 [Электронный pecypc]. URL: http://www.catiadesign.org/_doc/v5r14/catpdfehfug_C2/e hfug.pdf (дата обращения: 06.10.17).

15. Новиков И., Бубнов А. Проектирование электрических систем от Dassault Systemes и IGE+XAO Group [Электронный ресурс] // САПР и графика. 2006. № 1. URL: http://www.sapr.ru/article.aspx? $\mathrm{id}=14860 \& \mathrm{iid}=705$ (дата обращения: 26.01.17).

(C) Butin A. M., Dubrovskiy E. U., Dobyshev E. V., Efremov S. V., Suntsov S. B., 2018 